\title{
Developments and prospects in the metal and textile industries of Macedonia
}

\section{Current economic situation}

\section{Key economic indicators}

According to the 2009 Report of the World Bank, Macedonia has made great strides over the last four years. There has been active support for the country by this institution in terms of strengthening its competitiveness for sustainable economic growth; improving the business environment; strengthening human capital; improving the transport and energy infrastructure; and supporting the processes of decentralisation.

The brief conclusions made by this institution are that:

- Macedonia had growth below the regional average in the first half of the decade. Real GDP expanded more vigorously between 2006 and 2008, although with only modest improvements in living standards

- the country has weathered the crisis relatively well; however, short-term growth prospects remain uncertain

- Macedonia is facing the challenge of creating a foundation for strong and sustainable growth via a more diverse, competitive, socially inclusive and environmentally-sustainable economy.

The World Bank has provided significant support to Macedonia in its efforts to improve the business climate. The country has improved its ranking in the Doing Business survey to $32^{\text {nd }}$ out of 185 in 2009, becoming the third overall reformer in 2010. Improvements have been enabled with the new Law on Business Registration (the time needed to register a company was shortened to four days in 2009 from 48 in 2006; the costs of registering a business have been reduced to less than $€ 50$; a 'Regulatory Guillotine' has been introduced which streamlined more than 2000 laws and bylaws; etc).

Support has also been given in terms of investment in human capital, primarily through investment in education. This has helped increase secondary school enrolment from $85 \%$ to $95 \%$ between 2004 and 2008 and decrease the drop-out rate from $2.1 \%$ to $1.9 \%$. The state Matura examination was introduced and secondary education became obligatory by law.

Through its collaboration with the World Bank, Macedonia has improved the efficiency and sustainability of its energy sector and created an infrastructure development programme which has helped lower trade and transport-related costs.

The processes of decentralisation have also been supported, as a result of which 70 out of 83 municipalities in the country were able to settle their arrears by the end of 2008 . By the end of that year, arrears had fallen from around $\$ 100 \mathrm{~m}$ to around $\$ 16 \mathrm{~m}$.

The country's economic performance had improved considerably prior to the recent global economic crisis. The first decade of independence and transition was marked by numerous external and internal shocks, preventing the economy from growing at its 
full potential. The first positive growth rate was registered in 1996; however, the trend of accelerating growth rates was halted abruptly by developments in 2001 . Stabilisation over the last decade, coupled with stronger reforms, created the grounds for a more robust recovery. Average real GDP growth reached around 3.7 per cent from 2003-2006 and accelerated to around 6 per cent during 2007 and to 5 per cent in 2008, bringing the country's growth rate closer to the regional average.

However, gross national income per capita is far below that of the EU, and is also below the global and upper middle income average.

The pre-crisis expansion of output was the result of a strong track record of macroeconomic stability and generally prudent macroeconomic policies; strong demand for and prices of Macedonian exports (metals and garments); and buoyant domestic demand. Investors reacted to the improving business environment and the government's strong investment promotion campaign. At the same time, stronger competition in the banking sector increased the availability of credit and reduced the costs of financing. Finally, stronger growth resulted in modest employment and real wage growth.

The Macedonian economy has, so far, weathered the global economic crisis better than most countries in the region. The crisis resulted in a collapse of external demand and a sharp drop in private capital flows. The first signs of slowing growth emerged in the second half of 2008; by mid-2009, the economy was officially in recession and, as of the third quarter of 2009, GDP had contracted by 1.4 per cent. Nevertheless, the contraction has been less severe than experienced elsewhere in the region. This appears to be due to a slower adjustment in domestic demand, as a result of considerable fiscal expansion since late-2008, and the relatively healthy financial sector. The economy registered a positive growth rate in the last quarter of 2009, as construction and private consumption recovered somewhat, bringing the contraction for the year to -0.7 per cent.

The small economy is rather open and some sectors are very export-oriented, or export-dependent. However, foreign direct investment is still the weak point, since its level is below all other countries in the region in spite of all the efforts in the direction of the improvement of the business climate and legislation.

According to the EBRD, in the period January-April 2010, Macedonia had only $€ 70 \mathrm{~m}$ in FDI (compared to Montenegro - €164m; Croatia - €434m; Serbia - €386m; Bulgaria - €168m; and Romania - €754m).

The economy is projected to grow by 2 per cent during 2010, benefiting from continued fiscal expansion, improving demand and the prices of Macedonian exports, as well as a carefully-managed monetary policy. Even so, slower growth among the main trading partners and financial concerns may jeopardise the recovery. However, these projections are in the process of being reconsidered (according to the last EBRD report, growth will drop to $0.5 \%$, which is still a better expected result compared to most of the countries in the region).

According to the World Bank, the country faces a number of economic challenges, including:

- short-term growth prospects remaining depressed due to the global economic crisis. The economy appears to have stabilised, but the outlook is highly uncertain. The country's main trading partners continue to be significantly affected by the crisis, which may reduce export demand and foreign exchange inflows (current 
and capital). At the same time, domestic demand may continue to underperform as business and consumer confidence remain low. Early 2010 numbers suggest only a gradual recovery, although indirect indicators of economic activity suggest some recent acceleration

- gradual recovery requiring careful and rapid adjustment in macroeconomic policies. Fiscal policy is likely to be strained as weak domestic demand puts pressure on revenues and financing sources. The deficit target in 2010 does not indicate sustainability concerns, but financing the deficit domestically may still undermine efforts to increase credit to the private sector. Also, with revenues being somewhat optimistic, keeping the deficit at $-2.5 \%$ of GDP may require spending cuts

- going beyond the immediate impact of the crisis, achieving stronger and sustainable growth rates will require the creation of a more diverse, competitive and environmentally sustainable economy. Prudent macroeconomic policies are needed to narrow the fiscal and external imbalances over the medium-term, thus safeguarding debt sustainability, macroeconomic stability and managing the risks of potential new shocks and crises. The size of the fiscal consolidation required in Macedonia is smaller compared to other countries in the region, but addressing the spending rigidities and allocating resources to priorities will be a challenge. At the same time, infrastructure improvements combined with better human capital will create opportunities for faster growth. Improvements in the business environment, a reduction in the labour tax wedge and improvements in property rights should reduce the costs of businesses and improve competitiveness. Growth will increasingly have to come from environmentally-friendly sectors and policies - the country's current GHG emissions per unit of GDP are six times the EU-15 average

- preserving living standards in the short-run and improving them in the mediumterm will be a challenge. Even the stronger growth registered prior to the crisis failed to improve living standards substantially and these are now threatened by the impact of the crisis and the slow recovery. Absolute poverty continued to affect around one-fifth of the population prior to the crisis since stronger growth was offset by the surge in food and energy prices. The unemployment rate did decline, but jobs created were few and low-paid. Improving social inclusion and equity, and achieving better social outcomes, will be critical to sustain the momentum for reform, especially in a country as diverse as Macedonia, and if growth is jobless.

Regarding the Lisbon indicators, data obtained from the State Statistical Office reports as follows:

- the gross domestic product of Republic of Macedonia per head in 2006, calculated on the basis of purchasing power parities and expressed in purchasing power standards (PPS) is 6600 , or $28 \%$ of the European Union figure (EU-27=100), which is 23500

- the employment rate is $66.5 \%$ (employees as a percentage of the active population); while the general rate of employed people (as a percentage of the active and inactive population) was 37.5 in the first quarter of 2010

- business investment, measured through gross fixed capital formation, increased in 2008 by $20.7 \%$ compared to 2007 , while volume makes up $20.9 \%$ of GDP 
- the total active population (aged 15-64) in the first quarter of 2010 is 925613 people (615 962 in employment and 309651 unemployed). Out of the total number of employed people, the distribution by economic status is: 444664 employees; 34993 employers; 79381 self-employed; and 56925 unpaid family workers the educational background of the active labour force is structured as set out in Table 1:

Table 1 - Structure of the active population by education

\begin{tabular}{|l|c|c|}
\hline & $\begin{array}{c}\text { \% of active } \\
\text { population }\end{array}$ & $\begin{array}{c}\text { \% in unemployed } \\
\text { population }\end{array}$ \\
\hline $\begin{array}{l}\text { No education, incomplete primary } \\
\text { school and lower secondary education }\end{array}$ & $29.6 \%$ & $36.1 \%$ \\
\hline 3 years of secondary education & $12.2 \%$ & $12.8 \%$ \\
\hline 4 years of secondary education & $40.7 \%$ & $38.5 \%$ \\
\hline Higher level education (industrial college) & $3.1 \%$ & $2.2 \%$ \\
\hline Academic university level education & $14.4 \%$ & $10.4 \%$ \\
\hline
\end{tabular}

Source: State Statistical Office Statistical Yearbook 2009.

\section{Impact of transitional reforms}

The impact of transitional reforms has been simply devastating. In illustration, the indexes of industrial production in the period 1986-2007, where 1986 is taken as level 100, are as follows:

\section{Table 2 - Indexes of industrial production}

\begin{tabular}{|l|l|l|l|l|l|l|l|l|l|l|l|}
\hline $\mathbf{1 9 8 6}$ & $\mathbf{1 9 8 7}$ & $\mathbf{1 9 8 8}$ & $\mathbf{1 9 8 9}$ & $\mathbf{1 9 9 0}$ & $\mathbf{1 9 9 1}$ & $\mathbf{1 9 9 2}$ & $\mathbf{1 9 9 3}$ & $\mathbf{1 9 9 4}$ & $\mathbf{1 9 9 5}$ & $\mathbf{1 9 9 6}$ & $\mathbf{1 9 9 9}$ \\
\hline 100.0 & 102.4 & 100.7 & 105.0 & 93.9 & 77.7 & 65.4 & 56.3 & 50.4 & 45.0 & 46.5 & 47.2 \\
\hline $\mathbf{1 9 9 8}$ & $\mathbf{1 9 9 9}$ & $\mathbf{2 0 0 0}$ & $\mathbf{2 0 0 1}$ & $\mathbf{2 0 0 2}$ & $\mathbf{2 0 0 3}$ & $\mathbf{2 0 0 4}$ & $\mathbf{2 0 0 5}$ & $\mathbf{2 0 0 6}$ & $\mathbf{2 0 0 7}$ & $\mathbf{2 0 0 8}$ & $\mathbf{2 0 0 9}$ \\
\hline 49.3 & 48.1 & 49.7 & 48.2 & 45.6 & 47.8 & 46.8 & 50.0 & 51.8 & 53.7 & $56.6^{*}$ & $52.3^{*}$ \\
\hline
\end{tabular}

Source: State Statistical Office Publication 6.4.8.01/583.

* Calculated on the basis of published data 
Over (nearly) the same period, GDP had the movement shown below: Table 3 - GDP movement

\begin{tabular}{|c|c|c|c|c|c|c|c|c|c|}
\hline $\mathbf{1 9 9 0}$ & $\mathbf{1 9 9 1}$ & $\mathbf{1 9 9 2}$ & $\mathbf{1 9 9 3}$ & $\mathbf{1 9 9 4}$ & $\mathbf{1 9 9 5}$ & $\mathbf{1 9 9 6}$ & $\mathbf{1 9 9 7}$ & $\mathbf{1 9 9 8}$ & $\mathbf{1 9 9 9}$ \\
\hline- & -6.2 & -6.6 & -7.5 & -1.8 & -1.1 & 1.2 & 1.4 & 3.4 & 4.8 \\
\hline $\mathbf{2 0 0 0}$ & $\mathbf{2 0 0 1}$ & $\mathbf{2 0 0 2}$ & $\mathbf{2 0 0 3}$ & $\mathbf{2 0 0 4}$ & $\mathbf{2 0 0 5}$ & $\mathbf{2 0 0 6}$ & $\mathbf{2 0 0 7}$ & $\mathbf{2 0 0 8}$ & $\mathbf{2 0 0 9}$ \\
\hline 4.5 & -4.5 & 0.9 & 2.8 & 4.1 & 4.1 & 3.9 & 5.9 & 4.9 & -0.7 \\
\hline
\end{tabular}

Source: World Bank Country Report; State Statistical Office

The disintegration of the common state (Yugoslavia), and particularly the disintegration of the common market, was the most important factor which engraved, together with the wars in the region, the difficult transitional reforms. The simultaneous change in the economic and social systems was accompanied by a huge increase in criminality, corruption and other illegal activities.

The process of privatisation officially started in 1989, according to a special law where employees were offered the opportunity to buy-out the company's capital. This privatisation was accepted as valid with the newly-adopted law on privatisation in 1993. The privatisation of socially-owned capital is finished, although there is some part of state-owned capital that is still being offered for sale. The approach is on the model of paid privatisation (no vouchers are issued), in which employees gained some benefit in buying the shares of the company-employer.

After 2000, when the Stabilisation and Association Agreement on EU membership was signed, the transition reforms have proceeded along with the processes of preparation for EU accession.

The main impact of the transitional reforms has been on jobs and the employment rate, and on the level of poverty. In the former Yugoslavia, the unemployment rate is around $22 \%$ (Rahkola, Tevdovski and Stambolieva, 2009); but, in the 1990s, there were moments when it came near to $40 \%$ before stabilising at around $31 \%-35 \%$. At the same time, the employment rate is also low (36-37\%), while the size of the informal economy has been rather high throughout the whole period $(38.3 \%$ in $2006 / 07)$.

The ILO report (2008) says that $20 \%$ of the poor in the country are working poor, and not only those in informal employment but also those working in the formal economy. In addition, the percentage of those in poverty in the country has been continuously increasing (from approximately $20 \%$ in 1996 to $29.4 \%$ in 2007 , according to the State Statistical Office).

\section{Impact of financial crisis}

2009 was difficult year as a result of the effects of the global crises - as indeed it was in most of the rest the world. The negative trends were first felt in the last quarter of 2008 (although the year ended with total growth of $4.9 \%$ ) and continued into 2009 . There was negative growth of $-0.7 \%$ in 2009 (the first three quarters were negative 
although the last quarter was positive; and negative growth continued into the first quarter of 2010).

The situation is particularly critical in manufacturing industries, especially in steel and the non-ferrous industry, the production of components for the automobile industry and the textile industry.

However, compared to other countries in the region, it appears that the negative trends in Macedonia were the most mild. This is confirmed in the latest EBRD report, which confirms higher expectations for growth in Serbia (1.9\%) and Albania (1.4\%), but, for all other countries in the region, the predictions are lower than for Macedonia (0.5\%): Bosnia (0.4\%); Bulgaria (-1.3\%); Croatia (-1.3\%); and Romania (-3\%).

\section{Macroeconomic policies}

The state's monetary policy, created and conducted by the National Bank of Macedonia, can be qualified as restrictive and rigid. There are strict regulations on bank reserves, the obligatory reserve ratio, etc., which leads to restricted loan offers (indeed, the unavailability of loans) and high interest rates (particularly unattractive for the credit of industrial entities). However, this kind of monetary policy, together with changes in the system of financial transactions, has made the banking sector one of the fastest growing and most stable, even during the global crisis, although it remains fragmented. According to the EBRD, lending has become more restricted, and the annual growth of deposit has slowed significantly.

Overall, the eighteen banks in the country remain well capitalised, including through continued support by overseas parent banks. According to Bishev (2008), Macedonian banks had a $6 \%$ higher capitalisation than commercial banks in developed countries, and a $3.5 \%$ higher capitalisation than investment banks, while the coefficient of capital adequacy was $15 \%$ at the end of September 2008. In the same period, the public credit bureau increased its coverage while the voluntary pension insurance system became operational.

Fiscal policy is characterised by flat tax rates. There is a flat personal and income tax rate of $10 \%$, as part of the policy of attracting foreign investment. Re-invested income is free of taxation.

The general VAT rate is $18 \%$ and the preferential rate (e.g. for basic food items, etc.) is $5 \%$.

However, fiscal and monetary policies in the country are not co-ordinated (Rahkola, Tevdovski and Stambolieva, 2009). Fiscal policy is forcing strong public spending, which has a crowding out effect on the business sector. At the same time, the National Bank's monetary policy is strongly committed to maintain the informal peg to the euro (which is, together with the appreciation of the national currency, very often criticised by export-oriented companies and by some economic theorists), as well as macroeconomic stability. This is resulting in a continual tightening of monetary conditions, with the effect that it is becoming much more difficult for Macedonian companies not only to enter into investment activities but also, most importantly, to finance their current activities. 
The regulation on gross wages has been changed since 2009: employees are now personally obliged to pay tax and contributions out of the gross wage, with these calculated and paid on their behalf by the employer. Obligatory contributions out of the gross wage are being decreased between 2009 and 2011 (e.g. the pension insurance rate will decrease from $21.2 \%$ to $15 \%$; and the health insurance rate from $9.2 \%$ to $7 \%$ ) as part of the policy of decreasing labour costs.

However, the influence of the global crisis is that there are serious problems in the realisation of budget revenues and expenditure. Therefore, the decrease in the contribution rates has been postponed, but there is no additional taxation due to the crisis.

According to the Constitution, Macedonia is declared as a social country. Social security covers almost all citizens:

- employees, who pay insurance contributions

- retired people

- children whose parents are covered by insurance (up to the age of 26)

- unemployed people actively looking for a job; etc.

However, each month approximately 3-4\% of employees do not receive their wages, and unpaid contributions deny their right to health care and other payments from the Health Insurance Fund (such as pay for sick and maternity leave, etc.). The percentage of employees that does not receive wages regularly has dropped after the introduction of the new regulation related to gross wages; before that, it was around $8 \%$.

In the case of unemployment then, depending on the years of service, the unemployed person is entitled to a maximum of twelve months unemployment allowance, unless he is 59 or she is 57 . In that case, they are entitled to the allowance until retirement or new employment (which almost never happens).

Social welfare in different forms was provided to 52426 adults and 21479 minors in 2008 (World Bank country report). The number is decreasing, partly due to the rigid controls and partly due to a change in the regulations.

However, people with an unresolved civil status practically fall out of the system and are denied social security.

The process of the privatisation and restructuring of companies took more than ten years. For large companies, it was monitored by the IMF and (in the first cycle) was supported by special credit arrangements. However, the final result has been that socialand state-owned capital is mostly privatised. Today, the state has a majority of the capital of five companies of which two are in the defence industry, one is in chemicals, one in electrical equipment and one in the tobacco industry (which the state is trying to sell), for which a special law was brought in 2008. Therefore, the process of the transformation of capital (socially- and state-owned) and restructuring can be considered as complete.

However, it is worth mentioning that multinational companies have shown only minor interest in taking part in this process; therefore, their presence in the country is very low.

The promotion of investment is taken most seriously by the government. There are paid advertisements for the country and its potential worldwide; infrastructure has been built to a small number of export processing zones; and incentives are offered to in- 
vestors, together with benefits for employment in terms of tax and contributions reductions for a certain period of time, including for the paid training of employees. In spite of all this, the level of investment is very low.

The metal and textile industries

\section{Sectoral structure}

Breakdown of value added per sector

Statistical yearbooks show that manufacturing contributed $27.05 \%$ of GDP (at basic prices) in 2000 , and $28.7 \%$ in 2005 ; while it made up $17.31 \%$ and $18.44 \%$ respectively of value added.

Textile industries took a $10.02 \%$ share of manufacturing gross output in 2000 and $6.98 \%$ in 2005 ; and contributed $14.01 \%$ and $10.34 \%$ respectively of manufacturing value added. The metal industries participated in total manufacturing gross output to an amount of $25.15 \%$ in 2000 and $30.77 \%$ in 2005 ; taking a respective share of manufacturing value added of $20.13 \%$ and $18.93 \%$.

Trends in industrial production per sector

The Macedonian economy is small, but open. An export orientation is particularly characteristic both of the metal and the textile manufacturing sector. The textile sector is particularly sensitive to competition from cheap textile producers from the far east, while the metal sector adjusts its production volumes depending on the level of sale prices on the open market.

The impact of the global crisis has had a visible, but uneven, effect on production volumes. Steel and non-ferrous metals saw a decrease of $42.1 \%$ in 2009 compared to 2008; while automobile components dropped from $46 \%$ to $30 \%$; and the textile industry from $33 \%$ to $12 \%$.

\section{Sectoral specialisation}

The total output of textile products shows that the manufacture of clothing is dominant, while textiles manufacture has a lower output. This is due to the character of production: namely, the so-called lohn production system is dominant (i.e. production to order in which all materials are supplied by the order-giver, with the workforce being practically loaned to the production of the ordered products).

The Macedonian textile industry has a history since the beginning of the $20^{\text {th }}$ century, with an established tradition of sheep breeding (and wool production), as well as growing cotton. After the 1950s, the production of raw materials grew smaller and smaller; nevertheless, large textile capacities were built, both for fabrics (wool and cotton) and clothing production. Thus were promoted generations of well-trained and skilled textiles workers. After the 1990s, the industry went through a restructuring process which led to the break-up of the big industrial units, but the industry remains one of the biggest absorbers of labour in the country. With severe competition from the far east, the industry is still a respected partner on European and US markets mainly 
because of the quality of labour, especially in shirts/blouses and the production of socalled heavy clothing (suits for men and women and winter coats).

In metals, the most important sector is the manufacture of base metals. The steel and non-ferrous industry is particularly important to the national economy, although no particular strategy for this particular industry is being pursued (in spite of the $\mathrm{Na}$ tional programme for restructuring and transformation of the steel industry of $R M$, an obligation from Protocol 2 of the Stabilisation and Association Agreement).

\section{Employment structure}

The textile and metal industries are important to the national economy from the point of view of absorption of the labour force: textiles as an industry with a high absorption capacity; and metals as influential for investment and the introduction of new jobs.

Currently, after the processes of transformation and restructuring, the employment situation is shown in Table 4:

\section{Table 4 - Employment by sector}

\begin{tabular}{|l|c|}
\hline Sector & $\begin{array}{c}\text { No. employees } \\
\text { (2009) }\end{array}$ \\
\hline Manufacture of textiles & 1642 \\
\hline Manufacture of clothing & 44605 \\
\hline Manufacture of base metals & 5543 \\
\hline Manufacture of fabricated metal products & 7525 \\
\hline Manufacture of machinery and equipment & 1682 \\
\hline Manufacture of electrical machinery and apparatus & 4197 \\
\hline Manufacture of motor vehicles, trailers and semi-trailers & 816 \\
\hline Manufacture of other transport equipment & no data \\
\hline Manufacturing total & 123387 \\
\hline Total employment & 615962 \\
\hline
\end{tabular}

Source: State Statistical Office

The number of employees in these industries is variable, particularly in the most recent period as a result of the global crisis. However, the metal and textiles industries, have experienced a turbulent period in the last twenty years, as Table 5 highlights: 


\begin{tabular}{|c|c|c|c|c|c|c|c|c|c|c|c|c|c|c|c|}
\hline 육 & f & 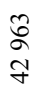 & $\begin{array}{l}2 \\
8 \\
7\end{array}$ & $\underset{n}{\mathfrak{f}}$ & $\begin{array}{l}\stackrel{n}{n} \\
\sim\end{array}$ & $\underset{0}{\mathscr{O}}$ & $\stackrel{\infty}{\infty}$ & $\frac{\hat{\sigma}}{\sigma}$ & $\frac{\circ}{\infty}$ & 0 & $\begin{array}{l}\frac{\partial}{\alpha} \\
\stackrel{े}{2}\end{array}$ & $\begin{array}{l}\text { مे } \\
\text { ते }\end{array}$ & $\frac{\hat{n}}{\infty}$ & $\begin{array}{l}\hat{\infty} \\
m \\
\tilde{\Xi}\end{array}$ & 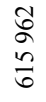 \\
\hline ڤ્ે & $\stackrel{\circ}{\sim}$ & $\frac{\partial}{\partial}$ & 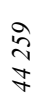 & $\stackrel{g}{\equiv}$ & \begin{tabular}{l}
\multirow{b}{0}{} \\
0
\end{tabular} & 음 & $\underset{\infty}{+}$ & 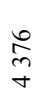 & $\stackrel{\cong}{=}$ & 太̃ & 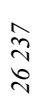 & $\stackrel{\infty}{\sigma}$ & 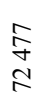 & $\begin{array}{l}\stackrel{2}{\hat{~}} \\
\stackrel{0}{0}\end{array}$ & $\begin{array}{l}\text { Бू } \\
\text { ลे }\end{array}$ \\
\hline$\stackrel{\text { స్ }}{\circ}$ & $\begin{array}{l}\mathcal{Q} \\
\infty \\
\sim \\
\sim\end{array}$ & $\frac{\infty}{\infty}$ & 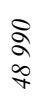 & $\begin{array}{l}\mathfrak{1} \\
\infty \\
0\end{array}$ & $\underset{\infty}{\text { సે }}$ & $\begin{array}{l}0 \\
\text { D } \\
-\end{array}$ & 范 & $\begin{array}{l}b \\
\sigma \\
\text { m) }\end{array}$ & $\begin{array}{l}\tilde{n} \\
\tilde{n} \\
-\end{array}$ & $\stackrel{\stackrel{\Xi}{\cong}}{=}$ & $\frac{\hat{n}}{\stackrel{\sim}{\sim}}$ & $\underset{\forall}{\stackrel{\Xi}{\Xi}}$ & $\begin{array}{l}\vec{D} \\
\stackrel{n}{7} \\
\stackrel{7}{0}\end{array}$ & 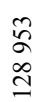 & $\begin{array}{l}n \\
0 \\
8 \\
8\end{array}$ \\
\hline હે & $\frac{n}{n}$ & 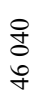 & $\frac{\hat{a}}{a}$ & $\underset{\sim}{\stackrel{\infty}{\sim}}$ & 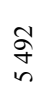 & $\widehat{\widehat{\Omega}}$ & $\dddot{q}$ & $\begin{array}{l}n \\
\infty \\
n\end{array}$ & $\stackrel{\overbrace{}}{=}$ & வ & $\begin{array}{l}\text { å } \\
\text { స }\end{array}$ & $\underline{\tilde{n}}$ & 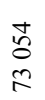 & $\begin{array}{l}\hat{\sigma} \\
\stackrel{\sigma}{\simeq}\end{array}$ & 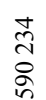 \\
\hline ڤ્సે & 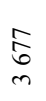 & $\frac{\vec{I}}{\stackrel{q}{q}}$ & $\begin{array}{l}\infty \\
2 \\
\approx\end{array}$ & 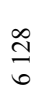 & $\underset{n}{\stackrel{0}{n}}$ & $\stackrel{8}{8}$ & $\stackrel{\Xi}{\Xi}$ & $\stackrel{\infty}{\stackrel{\infty}{r}}$ & $\bar{\sigma}$ & $\stackrel{n}{n}$ & $\begin{array}{l}\cong \\
\tilde{N} \\
\tilde{\sim}\end{array}$ & $\frac{\widetilde{J}}{\sim}$ & $\begin{array}{l}\stackrel{\mathfrak{r}}{\sim} \\
\stackrel{\infty}{0}\end{array}$ & $\begin{array}{l}\stackrel{0}{0} \\
\stackrel{\beth}{I}\end{array}$ & $\begin{array}{l}+ \\
\text { + } \\
\stackrel{2}{\text { in }}\end{array}$ \\
\hline 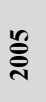 & $\frac{\hat{\sigma}}{\sigma}$ & $\begin{array}{l}\hat{\infty} \\
\infty \\
\stackrel{+}{q}\end{array}$ & $\begin{array}{l}\widetilde{1} \\
\infty \\
\approx\end{array}$ & $\underset{\sim}{\stackrel{尺}{N}}$ & 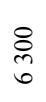 & $\begin{array}{l}0 \\
\stackrel{\sim}{N}\end{array}$ & $\stackrel{\text { }}{\circ}$ & $\frac{m}{\sigma}$ & $\begin{array}{l}\infty \\
i n \\
-\end{array}$ & ָ̊̀ & 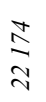 & $\stackrel{\text { N }}{\sim}$ & 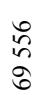 & $\begin{array}{l}\hat{n} \\
\hat{\Xi}\end{array}$ & $\begin{array}{l}n \\
\sim \\
n \\
i n \\
n\end{array}$ \\
\hline ڤ్ & $\underset{i}{\stackrel{f}{I}}$ & 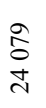 & $\begin{array}{l}\infty \\
\lesssim \\
\infty \\
\grave{\nu}\end{array}$ & $\stackrel{n}{n}$ & $\frac{0}{6}$ & $\underset{\sim}{\sim}$ & 0 & $\frac{n}{n}$ & $\begin{array}{l}+ \\
\infty \\
\infty \\
m\end{array}$ & 0 & $\underset{⿱ 亠}{\stackrel{D}{\sigma}}$ & 0 & 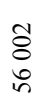 & $\begin{array}{l}\tilde{0} \\
\tilde{n} \\
\tilde{0}\end{array}$ & $\begin{array}{l}\frac{0}{2} \\
=\end{array}$ \\
\hline$\stackrel{2}{\varrho}$ & 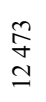 & $\begin{array}{l}\infty \\
\infty \\
\stackrel{n}{N} \\
\text { N }\end{array}$ & $\begin{array}{l}\hat{b} \\
\text { sे } \\
i\end{array}$ & 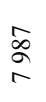 & $\begin{array}{l}\stackrel{0}{\hat{\sigma}} \\
\hat{\sigma}\end{array}$ & gे & 0 & $\begin{array}{l}\hat{b} \\
\infty \\
\infty\end{array}$ & $\begin{array}{l}\vec{n} \\
\infty \\
\forall\end{array}$ & 0 & $\begin{array}{l}\tilde{\approx} \\
\text { हे }\end{array}$ & 0 & $\begin{array}{l}\vec{a} \\
\sqrt[6]{6}\end{array}$ & 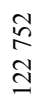 & $\begin{array}{l}\tilde{\sigma} \\
0 \\
\infty \\
m\end{array}$ \\
\hline 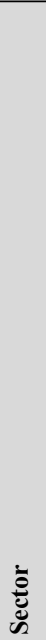 & 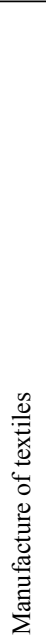 & 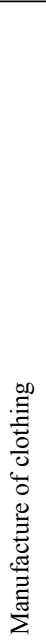 & 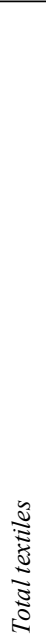 & 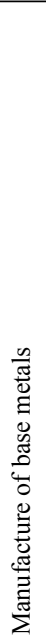 & 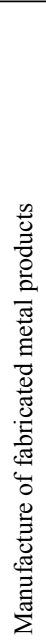 & 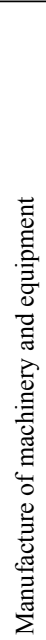 & 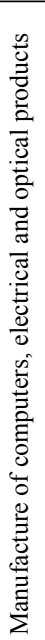 & 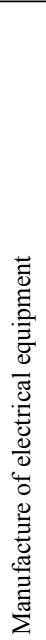 & 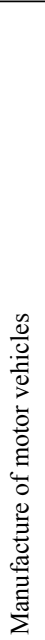 & 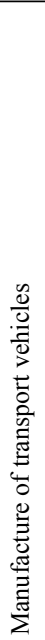 & 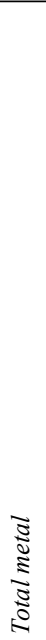 & 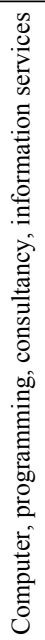 & 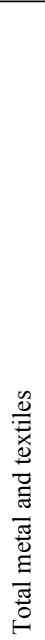 & 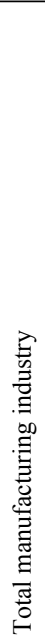 & 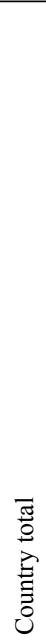 \\
\hline
\end{tabular}




\begin{tabular}{|c|c|c|c|c|}
\hline 을 & 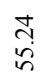 & $\stackrel{\text { ¿ }}{=}$ & $\frac{n}{6}$ & $\begin{array}{l}\infty \\
\stackrel{o}{0}\end{array}$ \\
\hline ڤ્సે & $\frac{1}{n}$ & $\stackrel{\sqrt[n]{\Xi}}{=}$ & $\underset{\dot{\sigma}}{\vec{j}}$ & 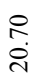 \\
\hline$\stackrel{\text { ڤ్ }}{\infty}$ & $\begin{array}{l}\text { o } \\
\text { in }\end{array}$ & 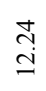 & $\frac{\text { aे }}{\dot{m}}$ & $\stackrel{\Re}{\stackrel{\infty}{\infty}}$ \\
\hline ڤ્ & $\begin{array}{l}\text { के } \\
\text { in }\end{array}$ & $\stackrel{\infty}{\stackrel{\infty}{\beth}}$ & $\begin{array}{l}\stackrel{\partial}{ } \\
\infty \\
\text { ळ) }\end{array}$ & $\stackrel{9}{\beth}$ \\
\hline ڤัڤ̆ & $\begin{array}{l}\text { fr } \\
\stackrel{n}{n}\end{array}$ & $\stackrel{\circ}{=}$ & $\begin{array}{l}n \\
\stackrel{n}{n} \\
m\end{array}$ & $\underset{\infty}{=}$ \\
\hline ڤ્ڤે & $\frac{2}{\hat{i}}$ & 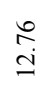 & $\underset{\substack{\infty \\
\infty \\
\sim}}{ }$ & $\begin{array}{l}\stackrel{g}{+} \\
\infty \\
-\end{array}$ \\
\hline હે & $\frac{\infty}{\vec{b}}$ & $\hat{a}$ & $\begin{array}{l}\infty \\
\infty \\
\infty \\
\sim\end{array}$ & $\underset{\tilde{n}}{\tilde{n}}$ \\
\hline ڤ̆ & $\begin{array}{l}\tilde{n} \\
\text { ñ }\end{array}$ & $\begin{array}{l}\mathcal{f} \\
\infty \\
\rightarrow\end{array}$ & $\begin{array}{l}0 \\
n \\
\infty \\
i\end{array}$ & 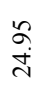 \\
\hline 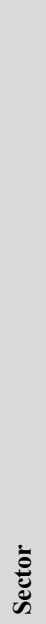 & 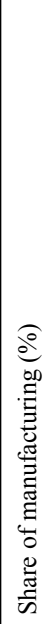 & 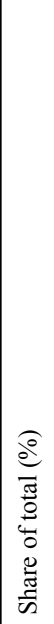 & 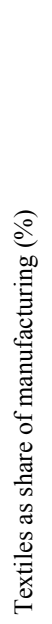 & 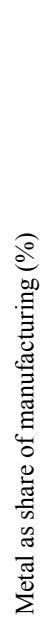 \\
\hline
\end{tabular}


According to the statistics, the textile industry reached its nadir around 2000, which means that the period of transformation and restructuring lasted over a decade. For a labour-intensive industry, the number of employees is a good indicator of the situation in the industry; therefore, the period between 1991 and 2000 (when a few large companies were transformed and privatised, as part of the IMF's so-called Financial Enterprise Structural Adjustment Loan arrangement) was the worst period, in which the industry fell from over 70000 employees to fewer than 30 000. After the large companies with 5000 workers and more had been restructured (often by being broken up into several smaller ones, made bankrupt and liquidated, and, after that, the capital offered for sale without the workers), and many small and medium newly-established companies had started to operate, the industry reached a new peak in 2007-2008 with almost 50000 workers. Then, the influence of the global crisis caused a contraction in the level of activity and this directly led to redundancies or even the closure of companies which had no more orders.

Even so, with around 45000 employees, the textiles industry engages over $7 \%$ of the total number of employees in the country and over $36 \%$ of workers in manufacturing. For Macedonia, a country with such a high rate of unemployment, this is a very important industrial sector.

At the same time, the metals sector has also gone through an equally rough period of restructuring and transformation; here, the number of employees in 1991 was around 45000 . Particularly in the most capital-intensive branches of the industry, such as steel and non-ferrous metals, the resolution of the problem of over-employment started in the middle of the 1980s. In those sectors, there were also some large companies with over 3000,5000 or 8000 workers prior to the transformation, which went under the same pattern dictated by the IMF (bankruptcy, liquidation, then the sale of the capital). Nowadays, the largest steel and non-ferrous companies have fewer than 1000 employees.

Branches in the metal industry engage almost $17 \%$ of manufacturing workers and around $3.5 \%$ of the total number of employees in the country.

Both sectors appear to be very important for the national economy as the most export-oriented sectors, with textiles being the absorber of a substantial number of workers and the metal sector as the bigger contributor to GDP.

\section{Productivity developments}

A basic economic axiom is that, for productivity to rise, greater levels of production are required with the same or less employment. However, in the case of the Macedonian textiles and metal industries, operating as they do in an open economy, the volume of production is dependent on the volume of orders (the contracts signed) and, ultimately, on the global market situation. With such quick changes in the global market as were observed in 2008 and 2009, the employment situation did not exactly follow the downturn in the market situation (changes in the number of employees came later).

According to the figures, there are more positive developments among metal industries than in the textile sector, but there are big cliff-edges in both sectors. This might be an indicator of bad judgment in planning the volume of production and the necessary 
labour for it. However, there is also more flexibility (to hire and fire) in more labourintensive sectors, such as textiles and the electrical equipment industry, for example.

\section{Labour costs - share of labour costs in value added}

The State Statistical Office has published average labour costs per employee for every other year since 2004. The data is given at headline level; no data by sector or industry branch is available. Table 6 shows labour costs data for manufacturing and in comparison with the national average.

Table 6 - Labour costs per hour actually worked (in denars)

\begin{tabular}{|c|c|c|c|c|c|c|c|c|}
\hline \multirow[t]{2}{*}{ Year } & \multirow{2}{*}{$\begin{array}{c}\text { Total } \\
\text { labour } \\
\text { costs }\end{array}$} & \multicolumn{3}{|c|}{ Compensation of employees } & \multirow{2}{*}{$\begin{array}{l}\text { Voca- } \\
\text { tional } \\
\text { training }\end{array}$} & \multirow{2}{*}{$\begin{array}{l}\text { Other } \\
\text { labour } \\
\text { costs }\end{array}$} & \multirow[t]{2}{*}{ Taxes } & \multirow{2}{*}{$\begin{array}{c}\text { Less: } \\
\text { Subsidies }\end{array}$} \\
\hline & & Total & $\begin{array}{c}\text { Wages } \\
\text { and } \\
\text { salaries }\end{array}$ & $\begin{array}{c}\text { Social } \\
\text { contrib- } \\
\text { utions }\end{array}$ & & & & \\
\hline $\begin{array}{l}2004 \\
\text { Man. }\end{array}$ & 124 & 116 & 80 & 37 & 2 & 1 & 8 & 8 \\
\hline $\begin{array}{l}2004 \\
\text { Av. }\end{array}$ & 146 & 135 & 92 & 44 & 1 & 2 & 10 & 25 \\
\hline $\begin{array}{l}2006 \\
\text { Man. }\end{array}$ & 136 & 127 & 87 & 40 & 2 & 2 & 8 & 20 \\
\hline $\begin{array}{l}2006 \\
\text { Av. }\end{array}$ & 161 & 150 & 102 & 48 & 1 & 2 & 11 & 51 \\
\hline $\begin{array}{l}2008 \\
\text { Man. }\end{array}$ & 140 & 134 & 91 & 43 & 1 & 2 & 6 & 6 \\
\hline $\begin{array}{l}2008 \\
\text { Av. }\end{array}$ & 173 & 164 & 113 & 51 & 2 & 3 & 8 & 23 \\
\hline
\end{tabular}

Source: State Statistical Office

According to official data, labour costs in manufacturing are around $15 \%$ lower than the national average. Also, the growth of labour costs in manufacturing in the 2004-2008 period (13\%) is less than the average growth of labour costs in the country as a whole $(18.5 \%)$.

The amount of hours actually worked in 2008 is 1845 (1 851 in companies in private ownership and 1835 in other types of organisation). The amount of paid hours currently is 2110 (2 102 in private ownership and 2124 elsewhere).

In the absence of statistical data for labour costs by sector, we can calculate a figure from the value of the compensation paid to employees (and published in the Statistical Yearbooks) divided by the number of employees and an approximate value of 2100 paid hours per year. 
Table 7 - Paid compensation per hour by sector (in denars)

\begin{tabular}{|l|c|c|c|c|}
\hline Sector & $\mathbf{2 0 0 5}$ & $\mathbf{2 0 0 6}$ & $\mathbf{2 0 0 7}$ & $\begin{array}{c}\text { Index } \\
\mathbf{2 0 0 7 / 2 0 0 5}\end{array}$ \\
\hline Total & 111.80 & 122.30 & 116.60 & 104.27 \\
\hline Manufacturing overall & 107.50 & 112.10 & 110.00 & 102.37 \\
\hline Textiles and clothing manufacture & 68.60 & 65.40 & 73.40 & 107.03 \\
\hline $\begin{array}{l}\text { Base metals and fabricated metal } \\
\text { products }\end{array}$ & 134.50 & 136.90 & 146.10 & 108.60 \\
\hline Machinery and equipment & 128.60 & 134.80 & 120.40 & 93.62 \\
\hline $\begin{array}{l}\text { Computers, electrical and optical } \\
\text { products and equipment }\end{array}$ & 113.10 & 121.10 & 130.10 & 115.04 \\
\hline $\begin{array}{l}\text { Motor vehicles and transport } \\
\text { vehicles }\end{array}$ & 99.00 & 109.00 & 122.70 & 123.99 \\
\hline
\end{tabular}

Source: State Statistical Office

The value of paid compensation per hour per employee is somewhat different from the official data for labour costs per hour for manufacturing and the countrywide average, since this data is obtained by calculated values of the published figures. If we consult statistical data on value added per sector and compensation for employees paid in the same year for 2005-2007, the situation is as follows:

\section{Table 8 - Labour costs in value added}

\begin{tabular}{|l|c|c|c|}
\hline \multirow{2}{*}{ Sector } & \multicolumn{3}{l}{ Compensation as \% of value added } \\
\cline { 2 - 4 } & $\mathbf{2 0 0 5}$ & $\mathbf{2 0 0 6}$ & $\mathbf{2 0 0 7}$ \\
\hline Total & 38.54 & 40.06 & 34.98 \\
\hline Manufacturing overall & 56.70 & 52.02 & 40.87 \\
\hline Textiles and clothing manufacture & 88.59 & 82.85 & 71.40 \\
\hline Base metals and fabricated metal products & 42.49 & 34.48 & 22.71 \\
\hline Machinery and equipment & 60.84 & 52.64 & 35.17 \\
\hline Computers, electrical and optical products and equipment & 55.43 & 45.53 & 48.94 \\
\hline Motor vehicles and transport vehicles & 59.48 & 50.10 & 55.00 \\
\hline
\end{tabular}

Source: State Statistical Office

The figures illustrate the compensation paid to employees as a share of the total volume of value added. It is clear that there is a direct relationship between the participation of labour costs in total production costs and their share of the volume of value 
added. Namely, in the textile industry compensation takes the highest share of value added, adequate to the participation of labour costs in total costs. In the manufacture of machinery and equipment, labour has a higher share of total costs; hence, the share of value added is higher. On the other hand, in the manufacture of base metals and metal products, labour costs take a lower share of total costs, so the share of the volume of value added is lower, too.

However, it is noticeable that the compensation paid to employees as a percentage of value added is, year-after-year, contracting in the period under observation.

\section{Enterprise structure (based on employment)}

The State Statistical Office gives the following data concerning the size of manufacturing industry enterprises in 2008 (unfortunately, there is no data by sub-sector):

Table 9 - Business units by number of employees

\begin{tabular}{|l|c|c|c|c|c|c|}
\hline \multirow{2}{*}{ Employees } & \multicolumn{3}{|c|}{ Country total } & \multicolumn{3}{c|}{ Manufacturing } \\
\cline { 2 - 7 } & $\begin{array}{c}\text { No. of } \\
\text { units }\end{array}$ & $\begin{array}{c}\text { No. of } \\
\text { employees }\end{array}$ & $\begin{array}{c}\text { \% of } \\
\text { total }\end{array}$ & $\begin{array}{c}\text { No. of } \\
\text { units }\end{array}$ & $\begin{array}{c}\text { No. of } \\
\text { employees }\end{array}$ & \% of total \\
\hline $1-5$ & 182 & 536 & 0.43 & - & - & 0 \\
\hline $6-10$ & 328 & 1691 & 0.77 & 84 & 208 & 1.28 \\
\hline $11-25$ & 4296 & 23531 & 10.04 & 1421 & 5094 & 21.74 \\
\hline $26-50$ & 8882 & 68482 & 20.76 & 1887 & 12135 & 28.87 \\
\hline $51-100$ & 10917 & 85497 & 25.52 & 2276 & 21775 & 34.82 \\
\hline $101-300$ & 17705 & 140408 & 41.39 & 795 & 34437 & 12.16 \\
\hline $301-500$ & 391 & 37068 & 0.91 & 44 & 14065 & 0.67 \\
\hline $501-1000$ & 61 & 36122 & 0.14 & 26 & 15294 & 0.40 \\
\hline $1001-2000$ & 16 & 17688 & 0.04 & 4 & 4699 & 0.06 \\
\hline Over 2 000 & 3 & 23833 & 0.01 & - & - & 0 \\
\hline Total & 42781 & 434858 & 100.00 & 6537 & 107706 & 100.00 \\
\hline
\end{tabular}

Source: State Statistical Office Statistical Review 2.4.9.09

It can be seen from the table that the number of companies in manufacturing with fewer than 100 employees make up $86.71 \%$ of the total number of registered companies; however, they employ $36.4 \%$ of manufacturing employees. In contrast, the number of companies with more than 100 employees make up only $13.29 \%$ of the total number of registered companies, but they employ $63.6 \%$ of manufacturing employees. 


\section{Share of informal economy}

It is difficult to obtain official data on the informal economy: the State Statistical Office does not offer anything on this issue. The academic paper of Rahkola, Tevdovski and Stambolieva (2009) calls upon Friedrich Schneider (2009), who explored the size of the 'shadow economy' in 25 transition countries. According to Schneider, the proportion of the informal economy in Macedonia was around $34 \%$ in 1999/2000, whereas in $2006 / 2007$ it had risen to $38 \%$.

The Macedonian experts consulted by the media agree that the proportion of the informal economy is focused around a figure of $40 \%$ and that it absorbs a large proportion of the unemployed labour force. The unions also agree that the informal economy helps to keep the social peace in the country and constitutes a buffer to the pressures of the constantly high unemployment rate; therefore, it is not in the interest of the authorities to work towards a contraction of the share of the informal economy.

\section{Share of state-owned companies}

Registered companies are classified by the State Statistical Office into 'private ownership' and 'other type of ownership', which includes public ownership or state ownership. Business units are classified according to type of ownership in Table 10, which shows that private ownership is dominant, particularly in manufacturing. Regarding the textiles and metal sectors, there are almost no state-owned companies. After resolving restructuring and privatisation in those sectors, there are practically two business units (from the defence industry) that are still state-owned: one large (with almost 500 employees) and one small (with 25 employees). For the large company, a tender for the sale of the state-owned capital has been published and the procedure is in progress.

Table 10 - Business units according to ownership

\begin{tabular}{|l|c|c|c|c|c|c|}
\hline \multirow{2}{*}{ Employees } & \multicolumn{3}{|c|}{ Country total } & \multicolumn{3}{c|}{ Manufacturing } \\
\cline { 2 - 7 } & $\begin{array}{c}\text { Total no. } \\
\text { of units }\end{array}$ & Private & Other & $\begin{array}{c}\text { Total no. } \\
\text { of units }\end{array}$ & Private & Other \\
\hline $1-5$ & 182 & 148 & 34 & - & - & - \\
\hline $6-10$ & 328 & 236 & 92 & 84 & 61 & 23 \\
\hline $11-25$ & 4296 & 3633 & 665 & 1421 & 1406 & 16 \\
\hline $26-50$ & 8882 & 8037 & 834 & 1887 & 1868 & 18 \\
\hline
\end{tabular}




\begin{tabular}{|l|c|c|c|c|c|c|}
\hline \multirow{2}{*}{ Employees } & \multicolumn{3}{|c|}{ Country total } & \multicolumn{3}{c|}{ Manufacturing } \\
\cline { 2 - 7 } & $\begin{array}{c}\text { Total no. } \\
\text { of units }\end{array}$ & Private & Other & $\begin{array}{c}\text { Total no. } \\
\text { of units }\end{array}$ & Private & Other \\
\hline $51-100$ & 10917 & 9964 & 953 & 2276 & 2231 & 45 \\
\hline $101-300$ & 17705 & 15718 & 1987 & 795 & 721 & 74 \\
\hline $301-500$ & 391 & 264 & 127 & 44 & 39 & 5 \\
\hline $501-1000$ & 61 & 44 & 17 & 26 & 21 & 5 \\
\hline $1001-2000$ & 16 & 10 & 6 & 4 & 4 & - \\
\hline Over 2 000 & 3 & 1 & 2 & - & - & - \\
\hline Total & 42781 & & & 6537 & & \\
\hline
\end{tabular}

Source: State Statistical Office Statistical Review 2.4.9.09

Investment

The State Statistical Office keeps a record of gross fixed capital formation regarding investment, by economic sector and by the purpose of investment (buildings, machinery and equipment, and other).

In 2007, out of a total gross fixed capital formation of $71557 \mathrm{~m}$ denars in Macedonia, 10389 were manufacturing, of which investment in machinery and equipment makes up $38 \%$ to $41 \%$ of the total amount.

\section{Foreign direct investment}

From the available statistical data, foreign direct investment by investment activity in 2003-2007 was as follows:

Table 11 - Foreign direct investment by investment activity (\$000)

\begin{tabular}{|l|c|c|c|c|c|}
\hline Sector & $\mathbf{2 0 0 3}$ & $\mathbf{2 0 0 4}$ & $\mathbf{2 0 0 5}$ & $\mathbf{2 0 0 6}$ & $\mathbf{2 0 0 7}$ \\
\hline Manufacturing & 35936 & 38586 & 53989 & 50498 & 72982 \\
\hline Country total & 80643 & 139460 & 116168 & 350665 & 330802 \\
\hline$\%$ manufacturing investment & 44.56 & 27.67 & 46.47 & 14.4 & 22.06 \\
\hline
\end{tabular}

Source: State Statistical Office Statistical Review 3.4.9.01

According to statistical information from the National Bank in 2009, the stock of FDI has grown steadily every year between 2003 and 2008: from $€ 1.3 \mathrm{bn}$ to $€ 2.97 \mathrm{bn}$. However, the share held by manufacturing, while rising in the first few years of the period from $38 \%$ of the total to a peak of $43.7 \%$ in 2005 , has subsequently fell sharply to below $30 \%$ of the 2008 total. 
The total volume of FDI is not high; and certainly not at a level the authorities would like. However, from the FDI that has been placed in the country, manufacturing appears to be of significant interest to investors, taking the lion's share of the investment placed in every year, although with variable dynamics. The one sector which was more interesting to investors (i.e. with more investment than manufacturing) was financial intermediation in 2007, which attracted one-third of the total FDI placed in that year.

FDI comes predominantly from developed countries. However, the scope of FDI remains low and is very fragmented.

\section{Structure of trade}

The Macedonian economy is open and export-oriented, but is also highly importdependent. There is always a deficit in the trade balance of the country because the total level of imports has been higher than the total level of exports in the whole period since 1997, and is growing.

According to the statistics, Macedonia imports both raw materials and finished goods for final consumption, while among exports semi-finished products for further manufacturing is also dominant (except in textiles). Thus, the level of value added and the degree of processing is low.

For the textiles industry, the main trading partners come from Germany, Greece, Netherlands, Great Britain, Italy, USA, Serbia, Turkey, Croatia and Belgium. To those countries $95 \%$ of exports are placed (the first three named taking $75 \%$ ). For metal industries, countries from the region (including Turkey) and the EU (in the broader context) are also the main trading partners. Transportation costs are important, so the nearest suppliers are most appreciated both as regards the import and the export of goods.

\section{Policy responses}

\section{General business environment}

According to all the assessments made by the European Commission, the International Monetary Fund, the European Bank for Reconstruction and Development, etc. Macedonia has made further progress on key reforms, geared towards integration into EU. The country acquired the formal status of EU candidate country in December 2005. The European Commission recommended, in October 2009, the opening of accession negotiations. That is confirmation that there is a certain political stability and progress in the country, although no decision has been made yet about the date for opening negotiations. However, it is clear that Macedonia still faces significant institutional and economic pre-accession reform challenges. In addition, the unsolved dispute over the country's official name has become an obstacle to further progress in the integration process.

The country has built a strong record of macroeconomic stability in last few years. GDP growth picked up to $5.9 \%$ and $4.8 \%$ in 2007 and 2008, respectively, led by stronger domestic demand and increasing investment, although the global economic crisis caused a downturn and a negative growth rate in 2009. Industrial production, capital inflows and investment dropped significantly and the metal and textiles sectors 
were hit particularly hard. The Macedonian economy exports a significant part of its industrial production to EU markets, so it is expected that economic recovery in the country's main export markets will contribute to a recovery of domestic growth potential and continued progress in the EU accession process.

Significant improvements in the business environment were achieved before the crisis. Taxes on corporate and personal income were reduced, a so-called 'one-stop shop' was introduced for business registration, reducing the time and costs of registering a business, and the bankruptcy legislation was also changed. Competition law has been strengthened and the Competition Office has proven its capacities to enforce competition policy. With the new law on obligatory contributions to social security, reductions have been made in the level of contributions, aiming to reduce labour costs in general. A 'regulatory guillotine' has been introduced, as have customs reforms. These improvements are reflected in the World Bank's Doing Business 2010 survey, where Macedonia is ranked 32nd out of 183 countries (the previous ranking was $69^{\text {th }}$ ), and third amongst the top ten reformers globally, with regard to business environment reforms implemented over the past year.

However, corruption and judicial shortcomings, together with the lack of an effective rule of law and the uncertainty of property rights, are undermining investment. The remaining problems concern dealing with permits, licences and authorisations, as well as bottlenecks in the bankruptcy process. Improvements to the judicial system and the functioning of courts are required to bring the country up to EU standards and to increase its attractiveness as an investment destination. Regarding the fight against corruption, the signs of progress contributed to Macedonia's ranking of $72^{\text {nd }}$ in the 2008 Transparency International Corruption Perceptions Index (previously 84th). Corruption in the award of public sector contracts in Macedonia is perceived to be less prevalent and less severe as regards business overall than in other south-east European countries. However, there are significant areas of concern in relation to corruption in dealing with the courts, the customer and infrastructure services. Therefore, the Prime Minister has recently appointed a former Romanian minister of justice as his special anti-corruption adviser.

The Law on the Civil Service was passed and, according to it, the appointment of civil servants must be independent of political parties. This is not yet felt in practice since, so far, civil servants have been appointed mostly according to political party membership. This contributes to a lower capacity of the administration in general and to possibilities for corruption.

The process of privatisation is almost finished and, in the metal and textiles sectors, there is an absolute dominance of private companies. Private entrepreneurship and initiative are enhanced through positive changes in the legislation, particularly in the alleviation of market entry and exit.

Despite positive GDP growth rates between $4 \%$ and $6 \%$ in the last five years, living standards remain far below the EU average, and social exclusion and poverty remain severe problems in the country. In terms of purchasing power parity, according to the EBRD, GDP per capita is just $25 \%$ of the EU average. There are also relatively high regional disparities (GDP in the capital Skopje is almost $50 \%$ of the EU average, which is far above the rest of the country). According to the State Statistical Office, $28.7 \%$ 
of the population in 2008 lived below the national poverty threshold, defined as having income lower than $60 \%$ of average household revenue.

The unemployment rate has been very high over the transition period - between $31 \%$ and $40 \%$ (the unemployment rate in the first quarter of 2010 was $33.8 \%$ ). Among the unemployed population, the group with education up to primary and lower secondary school makes up $37.7 \%$ of currently unemployed people. It is believed that changes in the labour legislation towards higher flexibility in the labour market (easing conditions for hiring and firing employees, facilitating the use of part-time contracts, agency workers and other forms of precarious employment, reducing minimum social contributions) would contribute to reducing the unemployment rate, but no noticeable results have been achieved: it is constantly one of the highest in Europe and among other countries in transition.

According to the EBRD, the financial sector has improved substantially in the recent period. Access to domestic sources of capital has improved in the past few years, driven by growing competition in the banking sector. Domestic credit to the private sector was around $43 \%$ of GDP in 2008, which is considerably higher than in previous years but still significantly lower compared to other countries in the region. However, the effects of the global crisis have had a negative impact on lending activities. Banks have tightened credit approvals; therefore, funding sources are insufficient. This is particularly hard for export companies, since they cannot source operating capital for their current activities.

The country's investment needs are still considerable. The government has an ambitious programme of capital investment across various sectors, but has to take account of the constraints required to maintain budget discipline. On the other hand, FDI in Macedonia is among the lowest in the region, although there was a considerable increase from $\$ 331 \mathrm{~m}$ in 2007 to $\$ 598 \mathrm{~m}$ in 2008 , reflecting the government's efforts to improve the business climate (and particularly after Macedonia was invited to join NATO).

According to the EBRD, Macedonia is rated BB+ by both Standard \& Poor's and Fitch. In September 2009, S\&P upgraded the country's outlook to neutral from negative. This improved rating was based on a positive assessment with regard to the country's fiscal position, since it has the lowest fiscal deficit in the region, as well as its improved liquidity position following the issuing of a $€ 175 \mathrm{~m}$ Eurobond, inflows from SDR allocations and loans from the European Investment Bank and the World Bank.

The country has no arrangement with the IMF after the last stand-by arrangement expired in August 2008.

However, according to the EBRD Strategy 2010-2013, improving the general business environment, including the effective implementation of legal and administrative changes, still remains one of the key challenges.

According to the EBRD Strategy, Macedonia is the third European country (after Denmark and Lithuania) that has adopted the National Agenda for Corporate Social Responsibility (2008). This is an attempt to promote a concept that would contribute to increasing the competitiveness of businesses and strengthening the public-private dialogue in this area. The actual implementation of this agenda has to be further im- 
proved, although the legal framework for corporate governance and the protection of shareholders' rights is largely harmonised with EU regulations and OECD principles.

\section{Infrastructure: road, rail, water}

The Macedonian road network has been somewhat developed and reconstructed during the transition; however, the quoted problems with further development and (particularly) maintenance are accurate.

Macedonia was part of the Regional Roads project of the EBRD, which was signed in 2003. This project was evaluated as Satisfactory. The EBRD has agreed a total of $€ 80.5 \mathrm{~m}$ in investments. One notable investment was $€ 50 \mathrm{~m}$ to finance the improvement and upgrade of more than $400 \mathrm{~km}$ of regional and local roads that form part of a key regional network and provide connections to international road corridors. The improvement of these road links is expected to contribute not only to the economic development of Macedonia and its important agricultural sector, but will also improve links and trade with neighbouring countries and the EU.

In January 2009, the Bank agreed the Regional and Local Roads Rehabilitation Project which aims to strength the Agency for State Roads in line with the new Law on Roads, including the contracting out of all maintenance.

In the government's $€ 8$ bn investment programme for the next seven years, presented in 2009, infrastructure projects in transport, energy and environmental protection are pointed out as the areas of greatest importance.

One of the transition goals regarding the transport infrastructure still remains the development of the further involvement of the private sector in road management issues. According to the EBRD Strategy, the government is to be supported in developing motorway concessions, establishing public-private partnerships in this area. This model (except for the airports concession) is to be used in projects for the development of a motorway network of $800 \mathrm{~km}$ and in road toll projects. The Bank is to continue providing support for the development of the road network, particularly with an emphasis on key regional links, like Corridors VIII and X. For that purpose, the EBRD is committing to work with the other international financial institutions, in particular the European Investment Bank and the World Bank. Furthermore, the EBRD is committed to continue supporting the commercialisation of the road sector, with the main focus on ensuring a predictable and stable flow of funds and the further improvement of road maintenance.

There are two airports in Macedonia and efforts are being made to build a cargo airport in the eastern part of the country, suitable for the transport of agricultural products. The airports are given under concession to the Turkish company TAV, which has postponed reconstruction due to the global crisis. According to the media, the contract obliges the concessionaire not only for reconstruction but also for the building of the cargo airport. Therefore, the RBRD Strategy recommends the sound implementation of airport concessions.

The railways are in a very bad situation. The government is trying to restructure the public railway system; the first phase has been completed under which the railway company has been institutionally separated into infrastructure and operating compa- 
nies. The further development of the railway will be supported by finance from the EBRD for investment focusing on the key corridors and rolling stock. Also, further restructuring will be supported with a focus on establishing an adequate legal framework that would facilitate third parties to use the Macedonian railway network. The concept of joining the establishment of a joint regional railway body (or company), which is in discussion in Croatia, Serbia and Slovenia, has also been mentioned.

In the supply of water, the financial and operational performance of the municipal utility companies is mixed as collection rates are low by regional standards and there is weak cost control, while substantial network losses are common among smaller communities. The level of the tariffs for water and heating is generally low, but some municipal utilities do manage to cover their operational costs through their tariffs. The transition challenges remain substantial and linked to effective tariff reforms. Reform has been supported by the EBRD, with a single project in 2000 .

\section{Promotion of investment}

The government has been trying hard to improve the level of investment with different kinds of measures. Macedonia has been advertised in the financial press as a good environment for investment; investment promoters have been appointed in several embassies; the legislation has been changed to enable certain subsidies and tax exemptions; a special ministry for the attraction of foreign investment has been established; etc. The Law on Technological Industrial Development Zones was passed in 2007 and, so far, the infrastructure has been prepared for a few such zones. In spite of all this, the level of FDI has not been satisfactory.

The Low on Technological Industrial Development Zones guarantees subsidies in the form of tax exemptions (on profits and on personal incomes for employees); customs exemptions; the participation of the government in construction costs (for companies listed by Fortune Global 500 and Business Global 1200); participation in labour costs for training periods; etc.

At national level, there is the Macedonian Bank for the Support of Development, as well as an Agency for the Support of Development and an Agency for the Development of Entrepreneurship who are intended to deal with national projects and new investment. The government's Industrial Policy for the Republic of Macedonia 2009-2020 pays special attention to:

- increase of international co-operation and attracting FDI

- applicable research, development and innovation

- environmental technologies, products and services for sustainable development

- development of SMEs

- co-operation in clusters and networks.

According to the Law on State Aid, state aid might be provided for the support of exports or regional development, to save a company in difficulties or to assist reconstruction; and may compatible aid (for citizens) or horizontal aid (for research and development, environmental issues, enhancing employment, training, etc). 


\section{Sectoral/cluster policies}

According to the government's Industrial policy for the Republic of Macedonia 2009-2020, officially pursued areas are not specifically oriented to particular sectors. However, according to the specific strategies developed by the Ministry for the Economy, it is dedicated to developing energy, tourism and the textiles industry.

Co-operation in clusters and networks has started with the support of USAID and the German GTZ and several clusters, including in textiles and the automobile industry, have been established. The cluster for textiles was set up in 2003 and has around seventy members (with around 10000 employees, almost one-quarter of employees in the sector). In the recent period, this has dealt mostly with issues concerning the improvement of competitiveness. The cluster for the automobile industry was established in 2008 and has 25 members (22 companies with around 1900 employees and three institutions). The company members are all components producers (one large, a few medium and more small- and micro-enterprises). The cluster helps to establish contacts with prospective customers, monitor and advise members about trends in the automobile industry and advocates and promotes the interests of members.

However, the clusters are, thus far, more like other associations based on membership, not associations formed throughout and on the basis of business inter-connections and interests. Perhaps that is why some of the clusters went passive after the first (supported) project was over and the interest in forming clusters is not sufficient for the possible need, particularly in some sectors (agriculture, food industry, etc.).

\section{$R \& D$ and innovation policies}

The vision of Macedonian industrial policy between 2009 and 2020 is to establish a proactive industrial policy that will support the orientation of Macedonian industry towards the creation of products and services with higher value added, based on knowledge, innovation and co-operation.

The government recognises that the encouragement of applied research, development and innovation, together with increased investment in R\&D by the public and the private sectors, and greater co-operation between industry, scientific and research institutions and the government, is one of the most important priorities. The development of the technological infrastructure and technological development zones, the creation of new products and services, the increase in the application of new technologies, the employment and engagement of researchers with higher education and the better protection of industrial and intellectual property rights is a strategy that will be pursued in the coming years to facilitate long-term industrial competitiveness.

At the moment, R\&D consumption is very low. According to the WEF index of the Lisbon Review in 2008, Macedonia takes $66.5 \%$ of the EU-27 average for research, development and innovation while, according to its Global Index of Competitiveness, Macedonia is at a level of $63 \%$ of the EU-27.

\section{Labour market policies}

Despite positive GDP growth rates, living standards remain far below those in EU and social exclusion and poverty remain severe problems. 
The level of unemployment during the whole period of the transition has created problems for all government structures and the issue of employment and job creation has had a continuing high priority. Different policies and temporary measures for reducing unemployment have been applied, but without significant results. Companies have been encouraged to increase the number of employees through subsidies in personal income tax for a certain period, even subsidies for all social security contributions, but there have been no encouraging results even in the short term. Special subsidies for self-employment are offered through the National Agency for Employment. However, the $33.45 \%$ unemployed rate in the first quarter of 2010 is certainly one of the highest in Europe.

In the National Strategy for Employment 2010, the targeted goal was to increase the rate of employment from $37.9 \%$ in 2005 to $48 \%$ in 2010 (according to the State Statistical Office, the employment rate was $33.9 \%$ ). This rate in the first quarter of 2010 was $37.5 \%$. The dynamics (according to the SSO) are given in Table 13 below:

Table 13 - Rates of employment and unemployment, 2005-2010

\begin{tabular}{|l|c|c|c|c|c|c|}
\hline & $\mathbf{2 0 0 5}$ & $\mathbf{2 0 0 6}$ & $\mathbf{2 0 0 7}$ & $\mathbf{2 0 0 8}$ & $\mathbf{2 0 0 9}$ & $\mathbf{2 0 1 0 / I}$ \\
\hline Activity rate & 54.1 & 55.1 & 55.7 & 56.3 & 56.7 & 56.3 \\
\hline General employment rate & 33.9 & 35.2 & 36.2 & 37.3 & 38.4 & 37.5 \\
\hline Unemployment rate & 37.3 & 36.0 & 34.9 & 33.8 & 32.2 & 33.5 \\
\hline
\end{tabular}

Source: State Statistical Office

The National Strategy for Employment is being implemented through periodical national employment plans. In spite of the results, which are neither encouraging nor close to the targets settled within the Strategy, policies for increasing the general employment rate and decreasing the unemployment rate are being persistently pursued. They are interconnected with measures for:

- sectoral growth

- entrepreneurship and SME support

- reducing the informal economy

- support for research, development and innovation, etc.

Among these measures are:

- reducing the level of social contributions from $32 \%$ of the gross wage (in 2008) to $22.5 \%$ (in 2011)

- making secondary school enrolment obligatory

- decentralisation of faculties and university education available in more towns (the targeted aim is 3500 students per 100000 citizens)

- increasing possibilities for lifelong learning and informal education

- increasing co-operation between the business community, education institutions and the National Agency for Employment

- encouraging the social dialogue, etc. 


\section{Environmental and energy policies}

Macedonia is going through overall reform of the electricity sector, supported by the EBRD with a $€ 35 \mathrm{~m}$ loan towards a $€ 90 \mathrm{~m}$ upgrading programme. The state-owned power company ESM has been restructured and the electricity distribution sector has been privatised (to EVN-Austria). A new tariff methodology has been introduced and a new Law on Energy passed. The EBRD has financed a transmission interconnection line between Macedonia and Bulgaria, completed at the end of 2008. This project supports cross-border electricity trade as part of wider efforts to create a regional energy trading market. However, ensuring reliable power supplies is still a concern.

Macedonia has an important position in the regional transmission network and a key role to play in the ongoing development of a regional power market. The country has excellent potential for small-scale hydropower and possibly wind power. Exploitation of this potential, according to the EBRD Strategy, requires a focus on the remaining barriers to investment.

EBRD aims to focus on investment in new and rehabilitated generation capacity to alleviate the growing capacity problems and improve the efficiency and environmental performance of the existing infrastructure. The Bank will also focus on investment in renewable and sustainable energy to address the current high carbon intensity.

The Ministry of Environmental and Physical Planning oversees the process of environmental management within the guidelines of the National Environmental Action Plan and the National Plan for Approximation to the Acquis. According to the EBRD, the institutional framework is well-developed, although co-operation and the distribution of responsibilities between the institutions needs further strengthening. Regarding environmental issues, good progress is recorded within horizontal legislation, but improvements are still needed in enforcement and administration capacities.

The National Strategy for Sustainable Development from 2008 establishes the short-term priorities for the implementation of environmental legislation and the development of environmental investment strategies.

The country has joined the UN Framework Convention on Climate Change and is a signatory to the Kyoto Protocol.

\section{Impact of international support measures}

Being a candidate country, expecting the opening of negotiations for accession to the EU, the possibility of accessing international support measures has increased. The country has access to different programmes and credit lines which contribute substantially to the processes of getting closer to European standards in all areas.

The EBRD has been operational in Macedonia since 1993 and, up to 2009 had agreed 58 projects across various sectors with a cumulative business volume of $€ 506 \mathrm{~m}$. With its finance, and the support of its partners and bilateral donors, the Bank has mobilised an additional $€ 593 \mathrm{~m}$. Between July 2006 and October 2009, the EBRD signed 14 new stand-alone projects worth $€ 132 \mathrm{~m}$, while an additional $€ 22 \mathrm{~m}$ was allocated under regional frameworks for different private sector projects.

Financing SMEs and micro enterprises through framework lending schemes with financial intermediaries and through EBRD Italy's Local Enterprise Facility will re- 
main a key instrument in the Bank's strategy up to 2013. The Bank will support industrial energy efficiency projects through a number of credit lines and financing facilities. The Bank has also committed to provide long-term funding to local commercial banks and assistance to local enterprises. In the agribusiness sector, debt and equity financing will be continued, while the Bank will also be involved in commercial real estate and hotel developments, where a large transition gap remains. In telecommunications, the Bank is committed to help with the roll-out of $3 \mathrm{G}$ and WiMAX networks.

The co-operation of international financial institutions is expected to benefit from the creation of the Western Balkans Investment Framework, which aims to consolidate financial instruments and the resources available to pre-accession countries.

Macedonia has also benefited from the different pre-accession programmes of the EU, such as IPA assistance in agriculture, CARDS projects, etc.

Macedonia officially joined CEFTA from 1 January 2006.

\section{Summary and policy conclusions}

Macedonia is a small country, with a population of a little over two million. Its per capita GNI is \$4 400 and purchasing power parity 10550 international dollars. The small market size creates certain limitations in the possibilities for industrial growth, while Macedonian metal and textiles industry capacities were sized according to the substantially bigger ex-Yugoslav market.

With the change in the social and economic system, Macedonia went through a period of transition involving the complete transformation and restructuring of industry. This process is still not completely over, but has been accelerated by Euro-Atlantic integration processes.

The manufacture of base metals and the manufacture of clothing are the only two sectors with a two-digit participation in exports. The textiles sector contributes $19.5 \%$ of the total exports of the country, while the metal sector makes up almost $40 \%$. This is the most significant indicator of the great importance of these two sectors in the Macedonian economy. Besides, they employ a substantial part of the labour force of Macedonia, where unemployment is one of the most significant and difficult problems.

The country is putting maximum effort into reaching sustainable development and long-term growth, towards which the improvement of all economic performance indicators is necessary. Among them, an increase in exports and the improvement of the trade balance is important. To increase the level of exports is not enough, but the country needs to increase the level of value added in exported goods and services. This means raising the degree of processing and exporting goods and services with a higher processing levels (finished goods rather than semi-finished products and raw materials). The metal sector currently exports semi-finished products, while the textile sector operates mostly on a lohn basis, with very little of its own products and designs. Manufacturing $R \& D$ costs are minimal, which means that companies pay very little attention to developing their own know-how which could bring higher revenues than renting machines and labour to contractors. The country has scarce and limited natural resources, so applied knowledge and skills might contribute much more to GDP growth and prosperity. 
Macedonia, as an EU candidate country, is putting great effort into attaining the accession criteria and required benchmarks, and the process of harmonising its legislation with the EU acquis has been speeded-up. Significant efforts are being directed to the improvement of the business environment, improving performance and enabling the faster growth of the economy and its sustainable development. In this context, economic policies are in favour of industry (including the metal and textiles sectors), increasing the employment rate, improving entrepreneurship and competitiveness, etc. Those efforts are fortified and supported by international support measures.

The country needs to work more on the utilisation of support from outside and increasing its own capacities. Significant results have been achieved in the improvement of business environment, the rule of law, the fight against corruption, reducing the share of the informal economy, etc. However, there is still much to do.

Public opinion is that accelerating the accession processes (which are delayed due to the political dispute with Greece over the issue of the name of the country) would have most positive impact, particularly from the point of view of FDI and the higher growth rate of the economy. 